\title{
Penambahan Gilsonite Resin Pada Aspal Prima 55 untuk Meningkatkan Kualitas Perkerasan Hot Mix
}

\author{
Rachmad Basuki \& Machsus \\ Staf Pengajar Program Diploma Teknik Sipil FTSP-ITS \\ email: rabas@ce.its.ac.id; machsus@ce.its.ac.id
}

\begin{abstract}
ABSTRAK
Pertamina bekerjasama dengan Perusahaan Swasta mulai memasarkan aspal jenis multigrade dengan merek dagang Aspal Prima 69/70, Prima 51 dan Prima 55 pada tahun 2004. Aspal Prima ini sekarang masih dalam taraf uji laboratorium dan uji lapangan. Berdasarkan hasil pengujian awal Sutarno (2004), ternyata aspal Prima 55 mempunyai titik lembek yang lebih rendah dari spesifikasi teknis yang ditetapkan. Dari latar belakang tersebut, timbulah ide untuk meneliti bagaimana jika Aspal Prima 55 yang sudah diproduksi oleh Pertamina tersebut ditingkatkan kualitasnya dengan modifier Gilsonite Resin sebagaimana penelitian sebelumnya untuk membuat perkerasan Hot Mix memenuhi spesifikasi dan lebih awet. Permasalahan yang ada adalah berapa prosentase kadar Gilsonite Resin yang harus ditambahkan pada campuran tersebut. Hasil pengujian kualitas Aspal Prima 55 menunjukkan bahwa sifat-sifat fisik aspal : penetrasi, titik nyala dan titik lembek tidak memenuhi spesifikasi aspal multigrade, kecuali berat jenis dan daktilitas. Penambahan Gilsonite Resin dalam penelitian ini menjadikan kualitas Aspal Prima 55 dapat memenuhi spesifikasi aspal multigrade, sehingga kualitas perkerasan Hot Mix jenis HRS B, AC dan ATB yang menggunakan aspal prima 55 dapat ditingkatkan.
\end{abstract}

Kata kunci: Aspal Prima 55, Gilsonite Resin, Hot Mix

\section{PENDAHULUAN}

\subsection{Latar Belakang}

Sesuai perkembangan teknologi Hot Mix, jenis aspal dibedakan menjadi tiga kelompok yaitu: aspal biasa (straight asphalt), aspal modifikasi (modified asphalt) dan yang terakhir adalah aspal multigrade (multigrade asphalt). Perkembangan jenis aspal ini tentunya sebagai upaya untuk meningkatkan perbaikan kinerja aspal sebagai pengikat agregat pada Hot Mix (campuran agregat dan aspal dalam kondisi panas untuk membuat bahan perkerasan jalan).

Di negara-negara maju, aspal multigrade sudah berkembang sejak tahun 1985. Beberapa produk yang terkenal antara lain : Multiphalt dari Shell dan Multibit dari British Petrolium (BP), dimana aspal-aspal tersebut belum dikenal luas di Indonesia.

Pada tahun 2000, Pertamina Unit Produksi IV Cilacap bekerjasama dengan Perusahaan Swasta mulai memproduksi aspal jenis multigrade dengan merek dagang Aspal Prima 69/70, Prima 51 dan Prima 55 yang mulai dipasarkan tahun 2004. Aspal Prima ini sekarang masih dalam taraf uji laboratorium dan uji lapangan, namun demikian jenis aspal ini merupakan salah satu yang akan digunakan untuk Proyek Jalan Jalur Pantura Pulau Jawa.

Berdasarkan hasil pengujian awal yang dilakukan oleh Sutarno (2004), disebutkan bahwa ternyata aspal Prima 55 mempunyai titik lembek yang lebih rendah dari spesifikasi teknis yang diberikan oleh yang memproduksi, sehingga dikhawatirkan jika digunakan perkerasan jalan nantinya tidak akan tahan dalam menerima temperatur udara yang tinggi di siang hari.

Disamping itu, menurut Henry (1987) Gilsonite Resin adalah salah satu modifier yang dapat memperbaiki sifat-sifat fisik aspal dan dapat meningkatkan kualitas perkerasan. Berpijak pada latar belakang tersebut diatas, kiranya perlu dilakukan penelitian bagaimana jika Aspal Prima 55 ditingkatkan kualitasnya dengan Gilsonite Resin untuk membuat Hot Mix.

\subsection{Perumusan Masalah}

Rumusan masalah dalam penelitian ini adalah :

a. Bagaimana sifat-sifat fisik aspal Prima 55 lainnya (selain titik lembek)? 
b. Bagaimana pengaruh campuran Gilsonite Resin pada Aspal Prima 55?

c. Bagaimana kualitas Hot Mix yang menggunakan aspal Prima 55?

d. Bagaimana kualitas Hot Mix Aspal Prima 55 yang ditambah dengan modifier Gilsonite Resin?

e. Berapa prosentase kadar Gilsonite optimum yang ditambahkan pada campuran Hot Mix Aspal Prima 55?

\subsection{Tujuan Penelitian}

Tujuan dari penelitian ini adalah :

a. Mengetahui sifat-sifat fisik Aspal Prima 55.

b. Mengetahui sifat-sifat fisik aspal Prima 55 setelah dicampur dengan Gilsonite Resin.

c. Mengetahui kualitas Hot Mix yang menggunakan aspal Prima 55 dari hasil Test Marshall dan Wheel Tracking.

d. Mengetahui kualitas Hot Mix Aspal Prima 55 yang ditambah dengan modifier Gilsonite Resin dari hasil Tes Marshall dan Wheel Tracking.

e. Menentukan prosen kadar Gilsonite Optimum yang ditambahkan pada Hot Mix Aspal Prima 55.

\subsection{Manfaat Penelitian}

Dengan kualitas perkerasan dan kepekaan terhadap pengaruh air yang semakin baik, maka hasil penelitian ini dapat diaplikasikan pada ruas-ruas jalan yang mempunyai beban lalu lintas yang berat, seperti Jalur Pantura maupun pada daerah yang rawan banjir, sebagaimana di Surabaya.

\section{LANDASAN TEORI}

\subsection{Aspal Prima 55 dan Hot Mix}

Aspal Prima 55 adalah termasuk dalam jenis aspal multigrade. Spesifikasi Aspal Multigrade ditunjukkan dalam Tabel 1.

Tabel 1. Spesifikasi Aspal Multigrade

\begin{tabular}{|c|c|c|c|c|}
\hline \multirow{2}{*}{ No. } & \multirow{2}{*}{ Jenis Pengujian } & \multicolumn{2}{|c|}{ Aspal Multigrade } & \multirow{2}{*}{ Satuan } \\
\hline & & Min & Maks & \\
\hline 1 & Penetrasi & 50 & 70 & $0.1 \mathrm{Mm}$ \\
\hline 2 & Titik Lembek & 55 & - & ${ }^{\circ} \mathrm{C}$ \\
\hline 3 & Titik Nyala & 225 & - & ${ }^{\circ} \mathrm{C}$ \\
\hline 4 & Daktilitas & 100 & - & $\mathrm{Cm}$ \\
\hline 5 & Berat Jenis & 1,0 & - & $\mathrm{Kg} / \mathrm{cm} 3$ \\
\hline 6 & Penurunan Berat (TFOT) & 0,8 & - & $\%$ berat asli \\
\hline 7 & Penetrasi setelah TFOT & 60 & - & $\%$ pen asli \\
\hline
\end{tabular}

Sumber: Spesifikasi Praswil (2003)
Menurut Sukirman S. (1999) Hot Mix adalah campuran agregat dan aspal semen dalam keadaan panas sebagai bahan perkerasan jalan. Jenis Hot Mix yang sering dipakai di Indonesia adalah AC (Asphalt Concrete), HRS (Hot Rolled Sheet) dan ATB (Asphalt Treated Base). Spesifikasi jenis-jenis hot mix tersebut seperti ditunjukkan dalam Tabel 2 s/d 4.

Tabel 2. Spesifikasi Lapis Perkerasan HRS B

\begin{tabular}{|c|c|c|c|c|}
\hline $\begin{array}{c}\text { Ukuran } \\
\text { Saringan }\end{array}$ & $\begin{array}{c}\text { Spesifikasi Gradosi } \\
\text { (\%ldos saringan) }\end{array}$ & $\begin{array}{c}\text { Stabilitas } \\
\text { Morshall, kg }\end{array}$ & $\begin{array}{c}\text { Marshdll } \\
\text { Quotient }\end{array}$ & $\begin{array}{c}\text { \%Rongga } \\
\text { dmcompuran }\end{array}$ \\
\hline 1 in & 100 & & & \\
$3 / 4$ in & 100 & & & \\
$1 / 2$ in & $60-100$ & & & \\
$3 / 8$ in & $57-83$ & & & \\
No.4 & $50-60$ & $550-1250$ & $1.8-5$ & $3-6$ \\
No.8 & $45-60$ & & & \\
No.30 & $15-60$ & & & \\
No.50 & $8-43$ & & & \\
No.100 & 425 & & & \\
No.200 & $2-8$ & & & \\
\end{tabular}

Untuk mendapatkan perkerasan yang baik, selain aspal, kualitas agregatnya pun harus memenuhi spesifikasi. Spesifikasi untuk agregat kasar dari CQMU 1988 sebagaimana ditunjukkan dalam Tabel 5. Sedangkan persyaratan yang harus dipenuhi agregat halus adalah : non plastis, bebas dari segala kotoran dan uji Sand Equivalent minimum $50 \%$. Untuk filler persyaratannya adalah material yang non plastis.

Tabel 3. Spesifikasi Lapis Perkerasan AC

\begin{tabular}{|c|c|c|c|c|}
\hline $\begin{array}{c}\text { Ukuran } \\
\text { Saringan }\end{array}$ & $\begin{array}{c}\text { Spec Gradasi } \\
\text { (\% lolos ) }\end{array}$ & $\begin{array}{c}\text { Stabilitas } \\
\text { Marshall, kg }\end{array}$ & $\begin{array}{c}\text { Marshall } \\
\text { Quotient }\end{array}$ & $\begin{array}{c}\text { \% Rongga } \\
\text { dlm camp. }\end{array}$ \\
\hline 1 in & 100 & & & \\
$3 / 4$ in & 100 & & & \\
$1 / 2$ in & $75-100$ & & & \\
$3 / 8$ in & $57-80$ & & $2.5-5$ & $3-5$ \\
No.4 & $52-77$ & $>1000$ & & \\
No.8 & $45-70$ & & & \\
No.30 & $20-45$ & & & \\
No.50 & $13-40$ & & & \\
No.100 & $8-26$ & & & \\
No.200 & $5-9$ & & & \\
\hline
\end{tabular}

Sumber : Spesifikasi Bina Marga. 
Tabel 4. Spesifikasi Lapis Perkerasan ATB

\begin{tabular}{|c|c|c|c|c|}
\hline $\begin{array}{c}\text { Ukuran } \\
\text { Saringan }\end{array}$ & $\begin{array}{c}\text { Spec Gradasi } \\
\text { (\% lolos ) }\end{array}$ & $\begin{array}{c}\text { Stabilitas } \\
\text { Marshall, kg }\end{array}$ & $\begin{array}{c}\text { Marshall } \\
\text { Quotient }\end{array}$ & $\begin{array}{c}\text { \% Rongga } \\
\text { dlm campuran }\end{array}$ \\
\hline 1 in & 100 & & & \\
$3 / 4$ in & $90-100$ & & & \\
$1 / 2$ in & $68-100$ & & & \\
$3 / 8$ in & $52-76$ & & & \\
No.4 & $47-65$ & $450-1500$ & $1.8-5$ & \\
No.8 & $38-58$ & & & \\
No.30 & $18-50$ & & & \\
No.50 & $12-40$ & & \\
No.100 & $8-28$ & & \\
No.200 & $2-8$ & & \\
\hline
\end{tabular}

Tabel 5. Gradasi \& Sifat-Sifat Teknis Agragat Kasar

\begin{tabular}{|c|c|c|c|c|c|c|}
\hline \multicolumn{2}{|c|}{ Ukuran Saringan } & \multirow{2}{*}{$\begin{array}{l}\text { \% lolos } \\
\text { agregat }\end{array}$} & \multirow{2}{*}{ Berat jenis } & \multirow{2}{*}{$\begin{array}{c}\text { Penyerapan } \\
\text { Agragat }\end{array}$} & \multirow{2}{*}{$\begin{array}{l}\text { Keausan } \\
\text { Agragat }\end{array}$} & \multirow{2}{*}{$\begin{array}{c}\text { Kelekatan } \\
\text { Agregat thd } \\
\text { Aspal }\end{array}$} \\
\hline & & & & & & \\
\hline 1 & 25.4 & 100 & \multirow{6}{*}{$2.5 \cdot 3.0$} & \multirow{6}{*}{ Maks 3\% } & \multirow{6}{*}{ Maks 40\% } & \multirow{6}{*}{$>95 \%$} \\
\hline $3 / 4$ & 19 & $90-100$ & & & & \\
\hline $1 / 2$ & 12.5 & 20-55 & & & & \\
\hline $3 / 8$ & 9.5 & $0-15$ & & & & \\
\hline №.4 & 4.75 & 0.5 & & & & \\
\hline No.8 & 2.36 & - & & & & \\
\hline
\end{tabular}

dan COMII 1988

Pada dasarnya Gilsonite resin merupakan salah satu bahan galian menyerupai aspal yang dikenal dengan nama asphaltites. Asphaltites mempunyai sifat titik nyala yang tinggi. Umumnya bahan ini dipergunakan untuk mengkilapkan perabotan (vernis) dan kertas karbon (Clarkson, 1992).

Gilsonite resin adalah mineral hidrokarbon yang sangat rapuh dan terdapat dalam kondisi murni. Hasil galian bahan ini adalah $90 \%$ gilsonite resin, dan hanya $0,6-1 \%$ kadar abu yang dikandungnya. Gilsonite resin tidak berbahaya bagi tubuh manusia, hal ini disebabkan gilsonite resin tidak bersifat carcinogenik (PT.Bima Kimia Citra, 1994).

\subsection{Sifat Fisik Gilsonite Resin}

Gilsonite resin mempunyai titik leleh yang cukup tinggi yaitu pada $175 \mathrm{C}$, sedangkan titik nyala dari bahan ini adalah $315 \mathrm{C}$ (PT.Bima Kimia Citra, 1994). Hal ini menunjukan bahwa bahan ini tidak mudah terbakar, sehingga memungkinkan untuk diadakan pencampuran pada campuran aspal panas tanpa terlalu banyak merubah prosedur pelaksanaan.

\subsection{Sifat Kimia Gilsonite Resin}

Gilsonite resin mempunyai kandungan asphaltene yang tinggi (70.9\%) apabila dibandingkan dengan bahan-bahan aditif lainnya, sebagai misal aspal Teinidad $(17,4 \%)$, Rose $(67,1 \%)$ dan SDA $(35,9 \%)$. Selain itu Gilsonite resin juga mengandung maltene sebesar $27 \%$ dan minyak $2 \%$. Untuk kandungan nitrogen Gilsonite juga mempunyai kadar yang lebih tinggi dibanding bahan lainnya yaitu $3,2 \%$ dimana aspal Teinidad $1.01 \%$, Rose $0.8 \%$ dan SDA 1.1\%. Dari sifat-sifat kimia yang dimiliki oleh Gilsonite resin ini diharapkan agar material ini dapat memperbaiki adhesi agregat dan juga water stripping.

\subsection{Marshall Test}

Konse pengujian Marshall diperkenalkan oleh Bruce Marshall, seorang Insiyur yang bekerja pada Departemen Jalan Raya negara bagian Mississipi . Pada tahun 1948 perkumpulan insiyur di Amerika Serikat memperkenalkan dan mengesahkan prosedur pengujian menggunakan Marshall Test, dan selanjutnya menetapkan kriteria dari mix design. Sejak tahun 1948 metode pengujian dengan menggunakan Marshall Test telah banyak dipergunakan oleh berbagai negara dalam pengijian campuran aspal (Brown, 1990).

Dari pengujian Marshall dapat diperoleh data mengenai sabilitas dan flow (kelelahan plastis) campuran. Dengan mengisi form Marshall Test dapat diperoleh nilai rongga terhadap aspal dan rongga terhadap campuran . Data-data tersebut selanjutnya dipergunakan untuk menetukan kadar aspal optimum. Adapun persyaratan-persyaratan yang harus dipenuhi yaitu Stabilitas, Rongga dalam campuran, Marshall Quotient untuk masing-masing jenis perkerasan adalah seperti terlihat pada Tabel 2 sampai dengan 4. 


\subsection{Wheel Tracking Test}

Wheel Tracking adalah alat yang digunakan untuk menguji ketahanan deformasi dari campuran aspal di laboratorium, yaitu untuk mengetahui deformasi yang terjadi akibat roda yang bergerak diatas permukaan benda uji dari campuran aspal panas (hot mix) pada suhu $60^{\circ} \mathrm{C}$. Roda penguji terbuat dari karet keras dengan berat 118 lb. Nilai deformasi diperoleh dari kedalaman permukaan benda uji akibat beban repetisi.

Dari hasil pengujian Wheel Tracking tersebut dapat diperoleh Stabilitas Dinamis (lintasan/mm) dan Kecepatan Deformasi ( $\mathrm{mm} / \mathrm{menit})$. Berdasarkan spesifikasi yang dikeluarkan Praswil 2003, Stabilitas Dinamis untuk campuran aspal panas minimal 2500 lintasan/mm.

\subsection{Gambaran Penelitian Sebelumnya}

Hasil penelitian yang sudah dilakukan oleh Puslitbang Jalan, Bandung maupun penulis mengenai additive Gilsonite, cukup memberikan peningkatan mutu dari karakteristik campuran perkerasan yg lebih berarti, yaitu : mengurangi rutting akibat pembebanan berat, mengurangi kepekaan terhadap perubahan temperatur dan pengaruh perendaman air, serta meningkatkan daya rekat/ikat dari aspal terhadap aggregat (Puslitbang Jalan, 1993).

Hasil penelitian yang telah dilakukan oleh Basuki R, 1997 adalah sebagai berikut : Dengan kadar Gilsonite opt 7.8\% dari kadar aspal opt $5.2 \%$ untuk jenis perkerasan Asphalt Concrete, hasil pengujian stabilitas dinamis memberikan nilai 1346 lint $/ \mathrm{mm}$ untuk sampel yang direndam selama 24 jam, sedangkan sampel tanpa penambahan Gilsonite dan tanpa perendaman hanya memberikan nilai 1320 lint $/ \mathrm{mm}$. Ini merupakan indikasi bahwa campuran dengan Gilsonite sangat tahan terhadap pengaruh air, misalnya pada kawasan yang rawan banjir.

\section{METODOLOGI PENELITIAN}

Material agregat yang diambil dari AMP kemudian ditest di laboratorium untuk diketahui sifat-sifat fisiknya apakah sesuai dengan sifat fisik yang disyaratkan pada spesifikasi. Material yang dipergunakan adalah material yang memenuhi persyaratan spesifikasi baik gradasi maupun sifat teknis lainnya. Material aspal semen diperoleh dari Perusahaan Swasta yang bekerjasama dengan Pertamina Unit Produksi IV Cilacap. Selanjutnya menentukan proposi campuran agregat agar dapat mendapatkan gradasi campuran yang sesuai dengan spesifikasi gradasi pada Tabel 2.2 sampai dengan 2.4 masing-masing untuk HRS, AC dan ATB. Kemudian membuat benda uji tanpa Gilsonite resin dengan variasi kadar aspal yaitu : $5 \%, 6 \%, 7 \%, 8 \%$ dan $9 \%$ baik untuk HRS, AC dan ATB.

Setelah dilakukan pengujian Marshall, maka dilakukan analisa untuk mendapatkan kadar aspal optimum. Dengan menggunakan kadar aspal optimum tersebut dibuatlah benda uji dengan menambahkan Gilsonite resin dengan berbagai macam variasi yaitu : $0 \%$, $6 \%$, $8 \%, 10 \%$ dan $12 \%$ dari aspal optimum. Setelah itu dilakukan pengujian Marshall untuk berbagai macam variasi kadar Gilsonite tersebut. Kemudian dilakukan analisa untuk menentukan \% kadar Gilsonite Optimum. Dengan menggunakan \% kadar Gilsonite Optimum dibuatlah benda uji (sampel) lagi untuk kondisi yang memerlukan perendaman dan non perendaman, guna mengetahui kepekaan terhadap pengaruh air. Kemudian dilakukan pengujian Marshall dan Wheel Tracking terhadap sampel-sampel tersebut.

Disamping itu juga dilakukan pemeriksaan terhadap sifat-sifat fisik aspal setelah dicampur gilsonite dengan beberapa variasi seperti diatas. Dari seluruh hasil pengujian maupun pemeriksaan tersebut kemudian dianalisa sehingga akhirnya diperoleh suatu kesimpulan. Tahapan penelitian ini meliputi: studi Literatur, menyiapkan material agregat, aspal dan gilsonite, pengujian di laboratorium, analisa data dan kesimpulan hasil penelitian. Secara skematis metodologi penelitian sebagaimana ditunjukkan pada Gambar 1.

\section{HASIL DAN PEMBAHASAN \\ 4.1. Pemeriksaan Agregat}

Hasil pemeriksaan agregat sebagaimana ditunjukkan dalam Tabel 6. dan Gambar 1. 
Tabel 6. Hasil Uji Sifat teknis Agregat

\begin{tabular}{|l|c|c|c|c|c|}
\hline \multirow{2}{*}{ Sifat-sifat Teknis } & \multicolumn{5}{|c|}{ Jenis Material } \\
\cline { 2 - 6 } & $\begin{array}{c}\text { Agregat } \\
\text { Kasar }\end{array}$ & $\begin{array}{c}\text { Agregat } \\
\text { Sedang }\end{array}$ & $\begin{array}{c}\text { Agregat } \\
\text { Halus }\end{array}$ & Pasir & Filler \\
\hline & & & & & \\
BJ bulk & 2.542 & 2.564 & 2.617 & 2.628 & - \\
BJ SSD & 2.582 & 2.599 & 2.660 & 2.670 & - \\
BJ apparent & 2.648 & 2.656 & 2.734 & 2.742 & 2.706 \\
Penyerapan, \% & 1.570 & 1.350 & 1.627 & 1.585 & - \\
Keausan, \% & 29.65 & 28.35 & - & - & - \\
Sand Equivalent, \% & - & & - & 98.16 & - \\
& & & & & \\
\hline
\end{tabular}

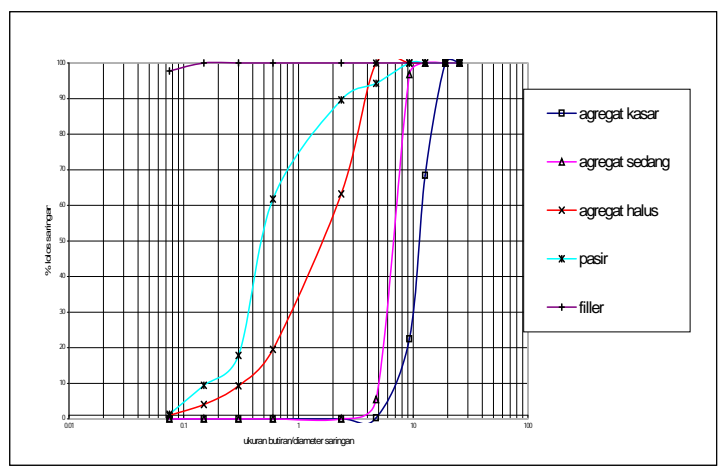

Gämbär 1. Hasil Änalisa Saringan Agregat

Berdasarkan hasil pengujian terhadap sifatsifat fisik agregat seperti yang ditunjukkan pada Tabel 6, maka material tersebut dapat digunakan sebagai bahan pembuat lapisan perkerasan, karena memenuhi semua spesifikasi yang terdapat pada Tabel 5, kecuali untuk persyaratan gradasinya yang tidak seluruhnya masuk dalam batas-batas persyaratan yang diberikan. Oleh karena itu dalam proses pembuatan proporsi campuran untuk ketiga jenis perkerasan yang dibuat, masih harus diberikankan tambahan material filler berupa semen agar dapat memenuhi spesifikasi gradasi.

Dengan mengacu pada Spesifikasi Bina Marga, proporsi agregat yang didapatkan untuk HRS B adalah sebagai berikut : $23 \%$ agregat kasar, $17 \%$ agregat sedang, $45 \%$ agregat halus, $10 \%$ pasir dan $5 \%$ filler. Untuk AC adalah sebagai berikut : $20 \%$ agregat kasar,5\% agregat sedang, $40 \%$ agregat halus, $30 \%$ pasir dan $5 \%$ filler. Sedangkan untuk ATB proporsinya adalah sebagai berikut : $33 \%$ agregat kasar, $10 \%$ agregat sedang, 40\% agregat halus, $10 \%$ pasir dan $7 \%$ filler.

\subsection{Pemeriksaan Aspal Prima 55}

Hasil pengujian dari Aspal Prima 55 ditunjukkan pada Tabel 7.

Tabel 7. Hasil Pengujian Sifat Teknis Aspal Prima 55

\begin{tabular}{|c|c|c|c|c|c|c|c|c|}
\hline \multirow[b]{2}{*}{ No } & \multirow[b]{2}{*}{ Pengyijan } & \multicolumn{5}{|c|}{ 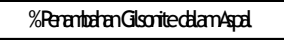 } & \multirow{2}{*}{$\begin{array}{l}\text { SpecAspd } \\
\text { Mltigace }\end{array}$} & \multirow{2}{*}{ Sathen } \\
\hline & & 0 & 6 & 8 & 10 & 2 & & \\
\hline 1 & Pendtai & 734 & 71 & 6.8 & 60.1 & 568 & $50-70$ & $0.1 \mathrm{~mm}$ \\
\hline 2 & Titklentrak & 4.5 & 525 & 58 & 635 & 6.5 & $>5$ & C \\
\hline 3 & Dakbilitos & 104 & 108 & 116 & 123 & T555 & $>100$ & $\mathrm{~m}$ \\
\hline 4 & TitkNyda & 198 & 218 & 29 & 23 & $2 B 8$ & $>255$ & C \\
\hline 5 & Bedtaris & 1.05 & 1.0288 & 1.085 & 1.02 & 1.023 & $>1$ & $\mathrm{~kg} / \mathrm{m} 3$ \\
\hline 6 & KefilagnnBedt & 0.05 & 0.033 & 0.031 & 0033 & 0.08 & $<08$ & \%terdsentat \\
\hline 7 & $\begin{array}{l}\text { Pendraisteddh- } \\
\text { kefilaggnbert }\end{array}$ & 567 & 4.3 & 4.8 & 406 & 368 & $>60$ & $\begin{array}{l}\text { \%penadi } \\
(01 \mathrm{~nm})\end{array}$ \\
\hline 8 & $\begin{array}{l}\text { Titiklentrekseddah } \\
\text { kefilangnberd }\end{array}$ & 53.5 & 59.5 & 61.5 & 64 & 71.5 & & C \\
\hline
\end{tabular}

Hasil pengujian kualitas aspal prima 55 sebelum diberikan tambahan Gilsonite sebagaimana terlihat pada Tabel 7.2 (pada kolom persen penambahan Gilsonite dalam Aspal $0 \%$ ) menunjukkan bahwa sebagian besar sifat-sifat fisik aspal yang diuji tidak memenuhi persyaratan yang diberikan (spesifikasi), yaitu penetrasi 73.4 (spec : 50 -70), titik lembek 47.5 (spec: > 55), titik nyala 198 (spec : >225), kecuali berat jenis dan daktilitas. Dengan demikian hasil ini sekaligus dapat memperkuat hasil penelitian yang dilakukan oleh Sutarno, bahwa aspal prima 55 masih perlu diperbaiki kualitasnya.

\subsection{Pengaruh Gilsonite pada Sifat Aspal Prima 55}

Pada penelitian ini dicoba untuk meningkatkan mutu aspal prima 55 dengan pemberian gilsonite yang bervariasi mulai $6 \%$ sampai $12 \%$ dari berat aspal sebagaimana yang ditunjukkan pada Gambar 7.2 Ternyata dengan penambahan 6\% dari berat aspal, sudah mulai terlihat adanya kenaikan kualitas sifat aspal, namun masih berada sedikit diluar batas spesifikasi. Pada penambahan kadar gilsonite $8 \%, 10 \%$ dan $12 \%$ keseluruhan sifat-sifat aspal dapat terpenuhi syarat-syarat spesifikasinya, kecuali pengujian daktilitas setelah kehilangan berat. Dari trend nilai yang didapat terlihat bahwa kualitas aspal prima 
55 dapat ditingkatkan mutunya setelah penambahan gilsonite $>6 \%$ dari berat aspal.

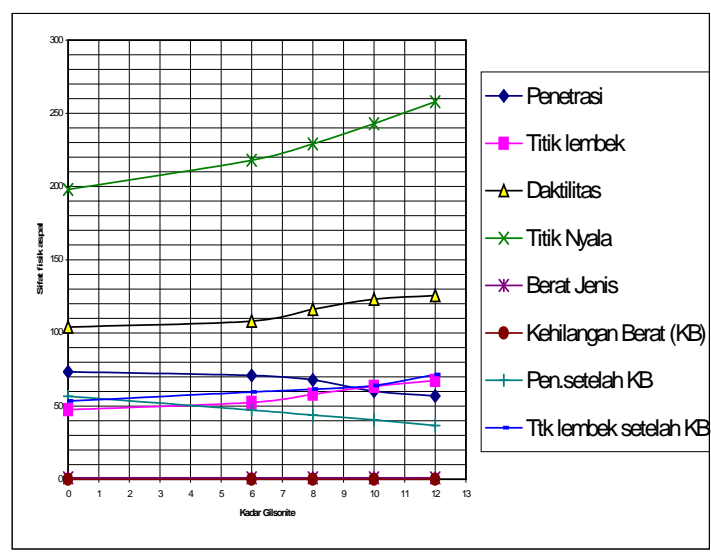

Gambar 2. Pengaruh Penambahan Gilsonite pada sifat teknis Aspal Prima 55

Bedasarkan hasil pencampuran yang dilakukan yaitu dengan penambahan kadar Gilsonite 6\%, 8\%, $10 \%$ dan $12 \%$ dari berat aspal, maka kecenderungan nilai penetrasi aspal makin menurun yaitu dari 73.4 pada kadar $0 \%$ menjadi 56,8 pada kadar $12 \%$ seperti terlihat pada Tabel 7. dan Gambar 2. Penurunan nilai penetrasi ini memberikan indikasi akan menjadikan meningkatnya tingkat kekerasan campuran sehingga menambah kemampuan mendukung beban berat. Pengaruh sifat fisik yang lainnya adalah semakin tinggi kadar Gilsonite semakin tinggi pula nilai daktilitas, titik nyala maupun titik lembeknya seperti ditunjukkan pada Tabel 7. Nilai daktilitas yang tinggi berarti tingkat kohesinya semakin baik tetapi lebih peka

Namun apabila didasarkan pada hasil titik lembeknya yang semakin tinggi (dari $53.5^{\circ} \mathrm{C}$ pada $0 \%$ Gilsonite menjadi $71.5{ }^{\circ} \mathrm{C}$ pada penambahan gilsonite $12 \%$, ini berarti kepekaan terhadap perubahan temperatur bisa direduksi, sehingga dari segi tes fisik saja sudah menampakkan peningkatkan kualitas dari aspal. Peninjauan terhadap sifat aspal juga dilakukan terhadap campuran aspal + modifier Gilsonite setelah dioven, yaitu pemeriksaan kehilangan berat aspal (TFOT). Tujuan pemeriksaan ini adalah untuk mengetahui pengurangan berat akibat penguapan bahan-bahan yang mudah menguap dalam aspal. Penurunan berat yang besar menunjukkan banyaknya bahan-bahan yang hilang karena penguapan, sehingga aspal tersebut akan cepat mengeras dan menjadi rapuh. Berdasarkan hasil pemeriksaan (Tabel 7.) yang diplotkan pada Gambar 2. tersebut, keseluruhan sifat fisik aspal dapat masuk dalam Spesifikasi Aspal Multigade adalah jika aspal prima 55 ditambah dengan Gilsonite pada kadar $=6.8$ \% dari kadar aspal, namun demikian tentunya harus dilakukan juga pengujian secara fisik terhadap sifat campuran (aspal + agregat) yang menggunakan aspal prima 55 + modifier gilsonite.

\subsection{Kualitas Hot Mix yang Menggunakan Aspal Prima 55}

Hasil akhir dari perhitungan data pengujian Marshall untuk campuran tanpa Gilsonite untuk jenis perkerasan HRS B dapat dilihat pada Gambar 3. Dengan mengacu pada spesifikasi pada Tabel 5., dibuatlah gambar untuk menentukan besarnya kadar aspal optimum sebagaimana ditunjukkan pada Gambar 4. Dari gambar tersebut didapatkan kadar aspal optimum untuk perkerasan HRS $B$ pada penelitian ini sebesar $7 \%$.

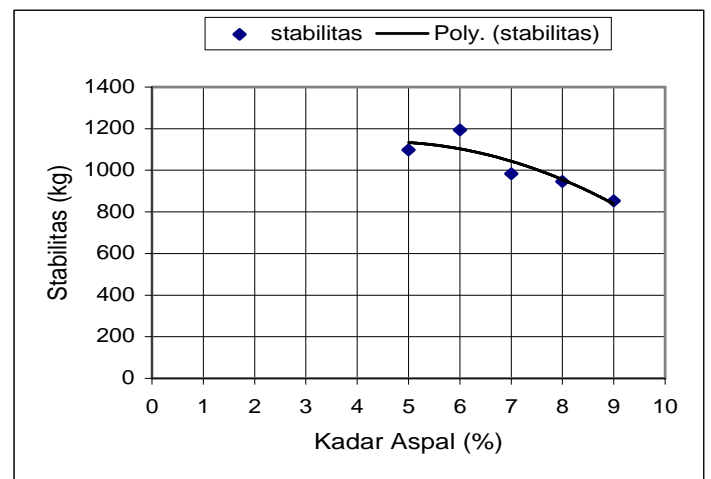

Gambar 3 (a)

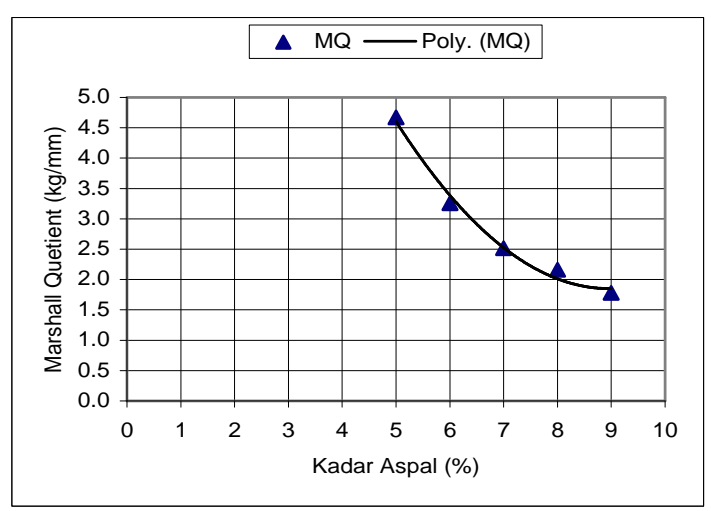

Gambar 3 (b) 


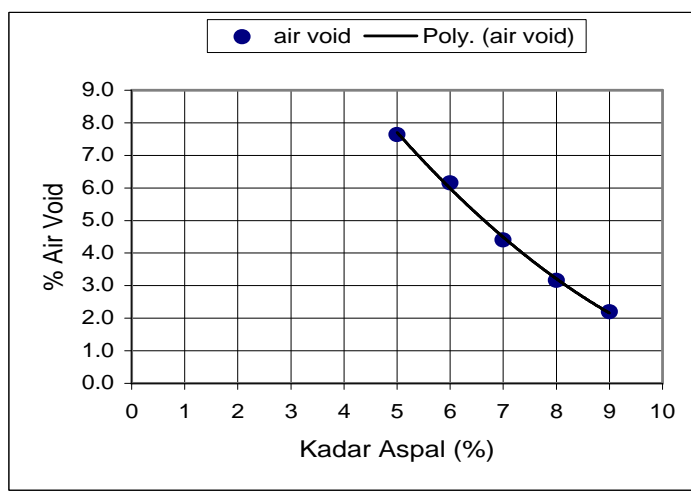

Gambar 3 (c)

Gambar 3. Hasil Analisa Marshall HRS B

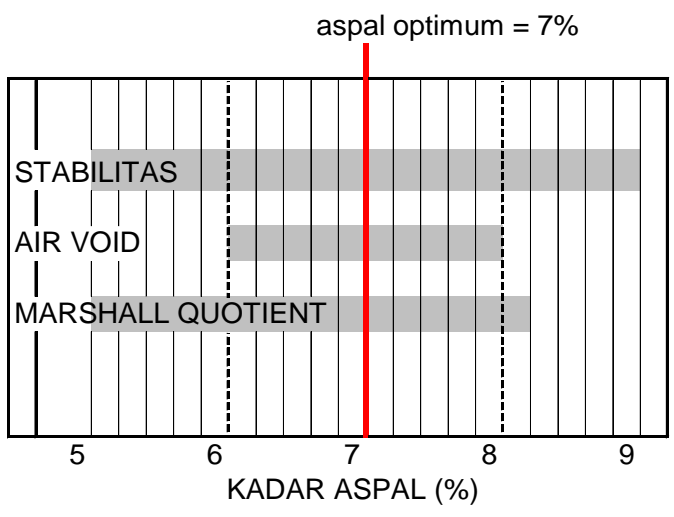

Gambar 4. Penentuan Aspal Opt. HRS B

Hasil akhir dari perhitungan data pengujian Marshall untuk campuran tanpa Gilsonite untuk jenis perkerasan AC dapat dilihat pada Gambar 5. Dengan mengacu pada spesifikasi pada Tabel 3, dibuatlah gambar untuk menentukan besarnya kadar aspal optimum sebagaimana ditunjukkan pada Gambar 6. Dari gambar tersebut didapatkan kadar aspal optimum untuk perkerasan AC pada penelitian ini sebesar $6.1 \%$.

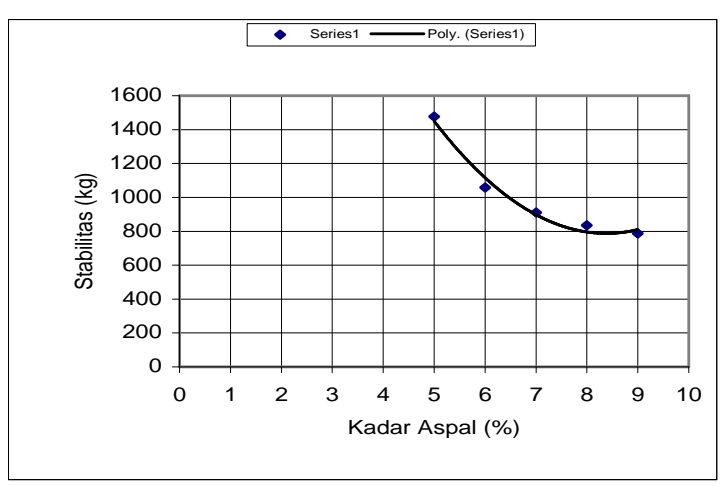

Gambar 5 (a)

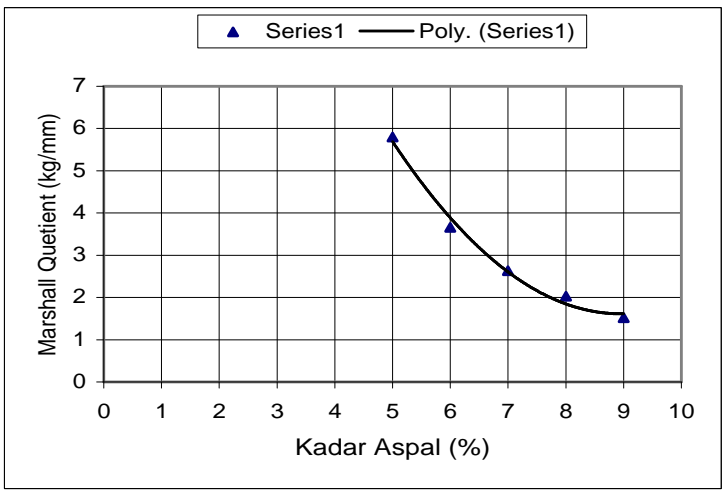

Gambar 5 (b)

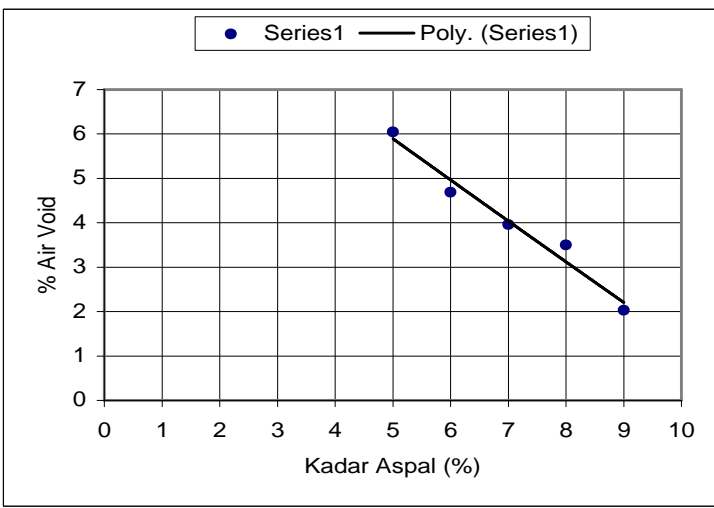

Gambar 5 (c)

Gambar 5. Hasil Analisa Marshall AC

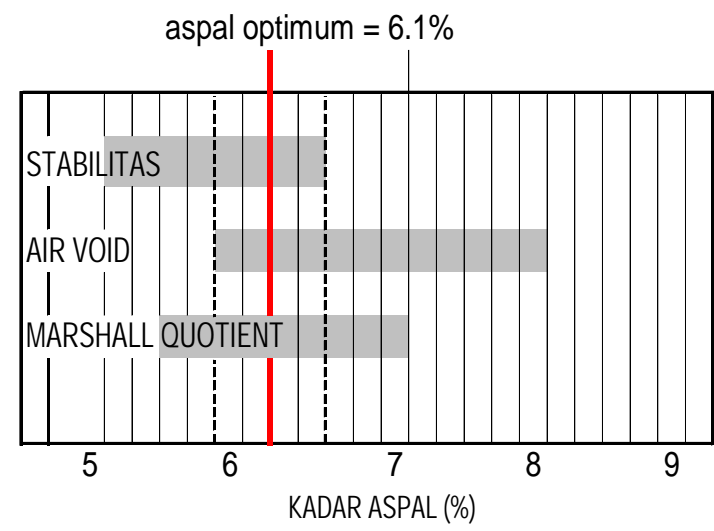

Gambar 6. Penentuan Aspal Opt. AC

Hasil akhir dari perhitungan data pengujian Marshall untuk campuran tanpa Gilsonite untuk jenis perkerasan ATB dapat dilihat pada Gambar 7. Dengan mengacu pada spesifikasi pada Tabel 4, dibuatlah gambar untuk menentukan besarnya kadar aspal optimum sebagaimana ditunjukkan pada Gambar 8. Dari gambar tersebut didapatkan kadar aspal optimum untuk perkerasan AC pada penelitian ini sebesar $6 \%$. 


\section{ISSN.1907-753X}

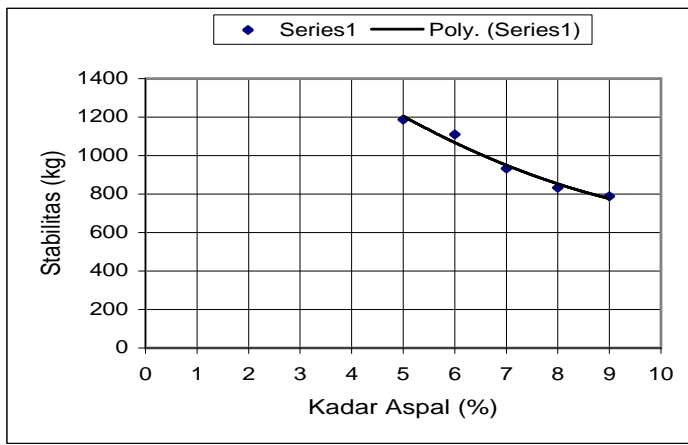

Gambar 7 (a)

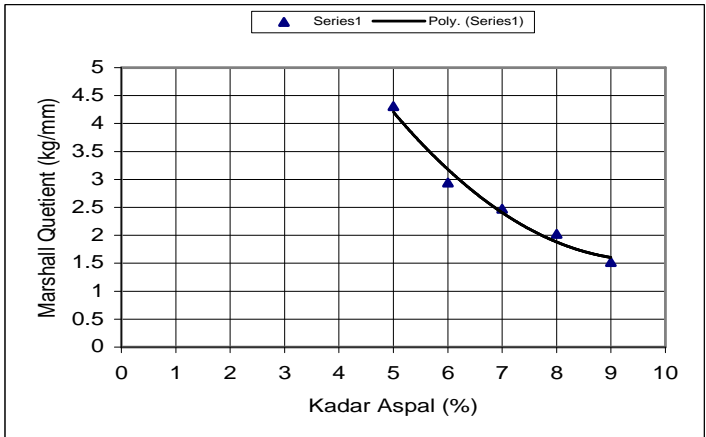

Gambar 7 (b)

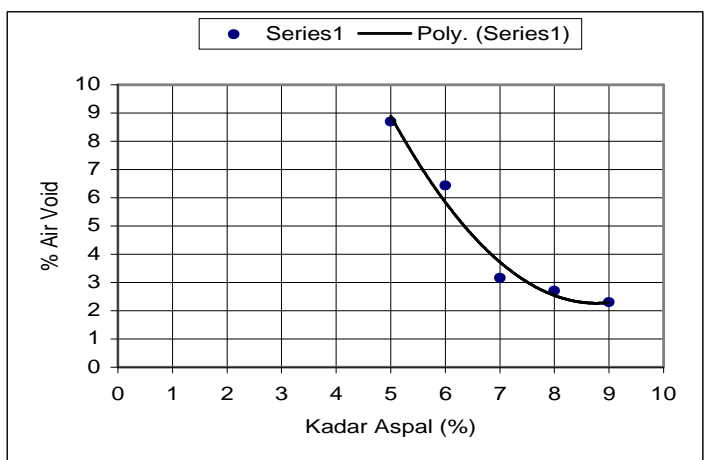

Gambar 7 (c)

Gambar 7. Hasil Analisa Marshall ATB

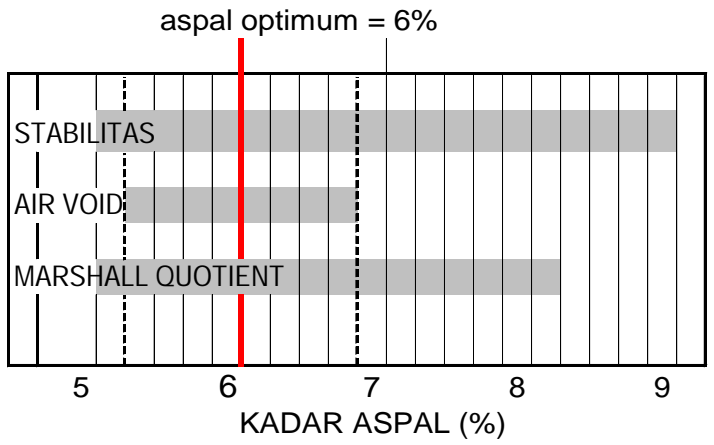

Gambar 8. Penentuan Aspal Opt. ATB

\subsection{Pemeriksaan Campuran Aspal dengan Alat Wheel Tracking}

Wheel Tracking adalah alat yang digunakan untuk menguji ketahanan deformasi dari campuran aspal. Pengujian ini dilakukan di Puslitbang Jalan Departemen Pekerjaan Umum Bandung. Hasil dari pengujian Wheel Tracking sebagaimana ditunjukkan dalam Tabel $8 \mathrm{~s} / \mathrm{d} 10$.

Tabel 8. Hasil Uji Wheel Tracking HRS B

\begin{tabular}{|c|c|c|c|c|c|c|c|}
\hline \multirow{3}{*}{$\begin{array}{l}\text { Waktu } \\
\text { (menit) }\end{array}$} & \multirow{3}{*}{$\begin{array}{l}\text { Passing } \\
\text { (lintasan) }\end{array}$} & \multicolumn{6}{|c|}{ Deformasi Benda Uji (mm) } \\
\hline & & \multicolumn{3}{|c|}{ 0\% Gilsonite Resin } & \multicolumn{3}{|c|}{$8 \%$ Gilsonite Resin } \\
\hline & & \begin{tabular}{|c|} 
Tanpa \\
Perendama
\end{tabular} & $\begin{array}{c}\text { Rendam } \\
1 \text { hari } \\
\end{array}$ & $\begin{array}{c}\text { Rendam } \\
2 \text { hari }\end{array}$ & \begin{tabular}{|c|} 
Tanpa \\
Perendama \\
\end{tabular} & $\begin{array}{c}\text { Rendam } \\
1 \text { hari } \\
\end{array}$ & \begin{tabular}{|c|} 
Rendam \\
2 hari
\end{tabular} \\
\hline 0 & 0 & 0.00 & 0.00 & 0.00 & 0.00 & 0.00 & 0.00 \\
\hline 1 & 21 & 1.21 & 1.24 & 1.24 & 0.91 & 1.05 & 1.18 \\
\hline 5 & 105 & 1.73 & 1.76 & 1.78 & 1.33 & 1.42 & 1.63 \\
\hline 10 & 210 & 1.95 & 2.00 & 2.03 & 1.65 & 1.77 & 1.92 \\
\hline 15 & 315 & 2.12 & 2.16 & 2.18 & 1.72 & 1.86 & 1.98 \\
\hline 30 & 630 & 2.43 & 2.55 & 2.58 & 1.98 & 2.11 & 2.22 \\
\hline 45 & 945 & 2.70 & 2.81 & 2.89 & 2.14 & 2.29 & 2.40 \\
\hline 60 & 1260 & 2.94 & 3.07 & 3.16 & 2.31 & 2.47 & 2.60 \\
\hline \multicolumn{2}{|c|}{$\begin{array}{l}\text { Laju Deformasi, } \\
\text { (mm/menit) }\end{array}$} & 0.0160 & 0.0173 & 0.0180 & 0.0113 & 0.0120 & 0.0133 \\
\hline \multicolumn{2}{|c|}{$\begin{array}{l}\text { Stabilitas Dinamis, } \\
\text { (lintasan/menit) }\end{array}$} & 2625.00 & 2423.08 & 2333.33 & 3705.88 & 3500.00 & 3150.00 \\
\hline
\end{tabular}

Tabel 9. Hasil Uji Wheel Tracking AC

\begin{tabular}{|c|c|c|c|c|c|c|c|}
\hline \multirow{3}{*}{$\begin{array}{l}\text { Waktu } \\
\text { (menit) }\end{array}$} & \multirow{3}{*}{$\begin{array}{c}\text { Passing } \\
\text { (lintasan) }\end{array}$} & \multicolumn{6}{|c|}{ Deformasi Benda Uji (mm) } \\
\hline & & \multicolumn{3}{|c|}{ 0\% Gilsonite Resin } & \multicolumn{3}{|c|}{$6.8 \%$ Gilsonite Resin } \\
\hline & & $\begin{array}{c}\text { Tanpa } \\
\text { Perenn }\end{array}$ & Rendam & Rendam & \begin{tabular}{|c|} 
Tanpa \\
Perendamn
\end{tabular} & Rendam & Rendam \\
\hline 0 & 0 & 0.00 & 0.00 & 0.00 & 0.00 & 0.00 & 0.00 \\
\hline 1 & 21 & 0.87 & 0.92 & 0.99 & 0.58 & 0.70 & 0.80 \\
\hline 5 & 105 & 1.24 & 1.37 & 1.53 & 0.87 & 1.00 & 1.15 \\
\hline 10 & 210 & 1.44 & 1.64 & 1.86 & 1.05 & 1.18 & 1.32 \\
\hline 15 & 315 & 1.58 & 1.81 & 2.07 & 1.17 & 1.30 & 1.44 \\
\hline 30 & 630 & 1.88 & 2.15 & 2.51 & 1.40 & 1.52 & 1.65 \\
\hline 45 & 945 & 2.10 & 2.42 & 2.79 & 1.54 & 1.65 & 1.78 \\
\hline 60 & 1260 & 2.29 & 2.62 & 3.02 & 1.65 & 1.76 & 1.90 \\
\hline \multicolumn{2}{|c|}{$\begin{array}{l}\text { Laju Deformasi, } \\
\text { (mm/menit) }\end{array}$} & 0.0127 & 0.0133 & 0.0153 & 0.0073 & 0.0073 & 0.0080 \\
\hline \multicolumn{2}{|c|}{$\begin{array}{l}\text { Stabilitas Dinamis, } \\
\text { (lintasan/menit) }\end{array}$} & 3315.79 & 3150.00 & 2739.13 & 5727.27 & 5727.27 & 5250.00 \\
\hline
\end{tabular}

Tabel 10. Hasil Uji Wheel Tracking ATB

\begin{tabular}{|c|c|c|c|c|c|c|c|}
\hline \multirow{3}{*}{$\begin{array}{l}\text { Waktu } \\
\text { (menit) }\end{array}$} & \multirow{3}{*}{$\begin{array}{r}\text { Passing } \\
\text { (intasan) }\end{array}$} & \multicolumn{6}{|c|}{ Deformasi Benda Uji (mm) } \\
\hline & & \multicolumn{3}{|c|}{$0 \%$ Gilsonite Resin } & \multicolumn{3}{|c|}{$9 \%$ Gilsonite Resin } \\
\hline & & $\begin{array}{c}\text { Tanpa } \\
\text { Perendaman }\end{array}$ & $\begin{array}{c}\text { Rendam } \\
1 \text { hari } \\
\end{array}$ & $\begin{array}{c}\text { Rendam } \\
2 \text { hari }\end{array}$ & $\begin{array}{c}\text { Tanpa } \\
\text { Perendaman } \\
\end{array}$ & $\begin{array}{r}\text { Rendam } \\
1 \text { hari } \\
\end{array}$ & $\begin{array}{r}\text { Rendam } \\
2 \text { hari } \\
\end{array}$ \\
\hline 0 & 0 & 0.00 & 0.00 & 0.00 & 0.00 & 0.00 & 0.00 \\
\hline 1 & 21 & 0.88 & 0.93 & 1.04 & 0.58 & 0.71 & 0.76 \\
\hline 5 & 105 & 1.25 & 1.39 & 1.57 & 0.86 & 1.02 & 1.14 \\
\hline 10 & 210 & 1.45 & 1.67 & 1.90 & 1.07 & 1.17 & 1.30 \\
\hline 15 & 315 & 1.59 & 1.83 & 2.10 & 1.15 & 1.31 & 1.43 \\
\hline 30 & 630 & 1.91 & 2.18 & 2.55 & 1.42 & 1.53 & 1.64 \\
\hline 45 & 945 & 2.12 & 2.45 & 2.83 & 1.56 & 1.65 & 1.75 \\
\hline 60 & 1260 & 2.33 & 2.67 & 3.09 & 1.68 & 1.78 & 1.90 \\
\hline \multicolumn{2}{|c|}{$\begin{array}{l}\text { Laju Deformasi, } \\
\text { (mm/menit) }\end{array}$} & 0.0140 & 0.0147 & 0.0173 & 0.0080 & 0.0087 & 0.0100 \\
\hline \multicolumn{2}{|c|}{$\begin{array}{l}\text { Stabilitas Dinamis, } \\
\text { (lintasan/menit) }\end{array}$} & 3000.00 & 2863.64 & 2423.08 & 5250.00 & 4846.15 & 4200.00 \\
\hline
\end{tabular}

Berdasarkan hasil analisa Marshall pada Gambar 4, untuk campuran HRS B besarnya kadar aspal optimum adalah 7\%. Dari uji Marshall didapatkan nilai stabilitas sekitar 
962 kg (spec : 550 - 1250 kg), Marshall Quotient 2.6 (spec : 1.8 - 5), \% Rongga dalam campuran 4.39 (spec : 3 - 6). Dari nilai-nilai tersebut di atas ternyata kualitas Hot Mix yang menggunakan aspal prima 55 masih memenuhi persyaratan teknis. Perendaman yang dilakukan sampai dengan 2 hari memberikan penurunan nilai stabilitas sampai dengan $883 \mathrm{~kg}$. Berdasarkan hasil pengujian Wheel Tracking (Tabel 9), kualitas hot mix HRS B yang menggunakan aspal prima 55 memberikan nilai stabilitas Dinamis 2625 lintasan/ menit (spec : > 2500 lintasan/ menit). Akan tetapi hasil perendaman selama 2 hari memberikan penurunan yang berarti terhadap Stabilitas Dinamisnya yaitu menjadi 2333 lintasan/ menit, yang artinya bahwa kualitas hot mix yang menggunakan aspal prima 55 kurang tahan terhadap pengaruh air.

Berdasarkan hasil analisa Marshall pada Gambar 5, untuk campuran AC besarnya kadar aspal optimum adalah $6.1 \%$. Hasil Uji Marshall untuk aspal opt tsb mempunyai nilai stabilitas sekitar $1058 \mathrm{~kg}$ (spec : > $1000 \mathrm{~kg}$ ), Marshall Quotient 3.54 (spec : 2.5 - 5), \% Rongga dalam campuran 4.43 (spec : 3 - 5). Dari nilai-nilai tersebut di atas ternyata kualitas Hot Mix yang menggunakan aspal prima 55 masih memenuhi persyaratan teknis. Perendaman yang dilakukan sampai dengan 2 hari memberikan penurunan nilai stabilitas sampai dengan $938 \mathrm{~kg}(<1000 \mathrm{~kg})$, yang artinya bahwa kualitas hot mix yang menggunakan aspal prima 55 kurang tahan terhadap pengaruh air. Berdasarkan hasil pengujian Wheel Tracking (Tabel 9), kualitas hot mix AC yang menggunakan aspal prima 55 memberikan nilai stabilitas Dinamis 3316 lintasan/ menit (spec : > 2500 lintasan/ menit). Akan tetapi hasil perendaman selama 2 hari memberikan penurunan yang berarti terhadap Stabilitas Dinamisnya yaitu menjadi 2739 lintasan/ menit.

Berdasarkan hasil analisa Marshall pada Gambar 6, untuk campuran ATB besarnya kadar aspal optimum adalah 6\%. Hasil uji Marshall pada kadar aspal opt. tsb memberikan nilai stabilitas $1294 \mathrm{~kg}$ (spec : 450 - $1500 \mathrm{~kg}$ ), Marshall Quotient 2.44 (spec : 1.8 - 5), \% Rongga dalam campuran 5.11 (spec : 3 - 6). Dari nilai-nilai tersebut di atas ternyata kualitas Hot Mix yang menggunakan aspal prima 55 masih memenuhi persyaratan teknis. Perendaman yang dilakukan sampai dengan 2 hari) memberikan penurunan nilai stabilitas sampai dengan $1057 \mathrm{~kg}$. Berdasarkan pengujian Wheel Tracking (Tabel 10), kualitas hot mix ATB yang menggunakan aspal prima 55 memberikan nilai stabilitas Dinamis 3000 lintasan/ menit (spec : > 2500 lintasan/ menit). Hasil perendaman selama 2 hari memberikan penurunan terhadap Stabilitas Dinamisnya yang begitu besar yaitu 2423 lintasan/menit, yang artinya bahwa kualitas hot mix untuk jenis ATB yang menggunakan aspal prima 55 kurang tahan terhadap pengaruh air.

\subsection{Pengaruh Gilsonite terhadap Sifat Campuran}

Dengan pemberian Gilsonite sebesar $8 \%$ dari $7 \%$ aspal optimum pada campuran HRS B, terjadi peningkatan yang cukup besar terhadap Stabilitas Marshall yaitu dari 962 menjadi $1422 \mathrm{~kg}$, namun diatas kadar gilsonite $8 \%$ nilai stabilitasnya cenderung menurun lagi. Sedangkan perilaku dari nilainilai Marshall Quotient dan \% Rongga dalam campuran untuk semua variasi kadar gilsonite yang dicoba $(6 \%, 8 \%, 10 \%$ dan $12 \%)$ keseluruhannya masih masuk pada range spesifikasi yang telah disyaratkan. Oleh karena itu untuk lapisan perkerasan HRS B yang menggunakan aspal prima 55 sebaiknya diberikan tambahan Gilsonite sebesar $8 \%$ dari aspal optimum.

Pemberian Gilsonite untuk campuran AC sebesar $6.8 \%$ dari $6.1 \%$ aspal optimum, memberikan peningkatan stabilitas Marshall yaitu dari $1060 \mathrm{~kg}$ menjadi sekitar $1300 \mathrm{~kg}$, namun diatas kadar gilsonite $6.8 \%$ nilai stabilitasnya cenderung menurun lagi. Sedangkan perilaku dari nilai-nilai Marshall Quotient (MQ) dan \% Rongga dalam campuran adalah sebagai berikut : pada kadar gilsonite diatas 10\% nilai MQ-nya berada di bawah $2.5 \mathrm{~kg} / \mathrm{mm}$ yang berarti keluar dari batas spesifikasi $(2.5 \mathrm{~s} / \mathrm{d} 5$ $\mathrm{kg} / \mathrm{mm}$ ), sedangkan pada kadar gilsonite $7 \%$ nilai \% rongga udara dalam campuran yang didapat sudah melebihi batas spesifikasi 5 , dimana batasnya adalah 3 sampai dengan 5 . Sehingga dapat disimpulkan bahwa kadar Gilsonite untuk jenis perkerasan AC dalam penelitian ini 
dapat diberikan sebesar $6.8 \%$ dari aspal optimum yang didapat.

Berdasarkan hasil analisa Marshall, untuk campuran ATB tanpa Gilsonite, besarnya kadar aspal optimum adalah 6\% . Nilai tersebut mempunyai stabilitas Marshall $1300 \mathrm{~kg}$. Stabilitas tersebut akan meningkat seiring dengan bertambahnya penambahan kadar Gilsonite, namun diatas 9\% tidak menampakkan kenaikan yang berarti. Sedangkan nilai Marshall Quotient dan \% rongga udara dalam campuran untuk semua variasi kadar gilsonite yang dicoba keseluruhan menunjukkan nilai yang masuk dalam range spesifikasi.

Berdasarkan hasil pengujian Wheel Tracking untuk ketiga jenis perkerasan (HRS B, AC dan ATB) yang menggunakan aspal prima 55 saja (tanpa dicampur gilsonite) untuk kondisi tanpa perendaman memberikan nilai Stabilitas Dinamis berturut-turut, 2625, 3315 dan 3000 lintasan/menit dengan laju deformasi berturut-turut $0.0160,0.0127$ dan $0.0140 \mathrm{~mm} /$ menit. Nilai-nilai Stabilitas Dinamis tersebut sudah memenuhi spesifikasi yang disyaratkan (yaitu 2500 lintasan/menit).

Sedangkan untuk sample yang telah dicampur dengan Gilsonite Resin (8\% untuk HRS B , 6.8\% untuk AC dan 9\% untuk ATB), hasil pengujian Wheel Tracking memberikan peningkatan nilai stabilitas yang cukup tinggi yaitu untuk HRS B 1.4 kalinya (dari 2625 menjadi 3705 lintasan/menit), sedang AC terjadi peningkatan 1.73 kali (dari 3315 menjadi 5727 lintasan/ menit) dan ATB terjadi peningkatan 1.75 kali (dari 3000 menjadi 5250 lintasan/ menit). Namun demikian untuk mengetahui pengaruh stabilitas terhadap perendaman air (jika struktur perkerasan dilapangan tergenang air banjir), maka diperlukan pengujian stabilitas benda uji pada sample yang terlebih dahulu direndam air selama 1 hari dan 2 hari.

\subsection{Pengaruh Gilsonite terhadap Perencaman Air}

Salah satu penyebab kerusakan lapisan perkerasan campuran aspal panas adalah akibat pengaruh genangan air pada perkerasan tersebut. Unsur Oksigen yang ada di air membantu terjadinya oksidasi pada aspal sehingga sifat-sifat adhesi maupun kohesinya akan hilang. Akibatnya aspal mudah terkelupas dari butiran agregat ataupun cracking jika diamati di lapangan. Tanda-tanda yang dapat dilihat dari kondisi ini di laboratorium adalah berkurangnya nilai stabilitas sampai dibawah nilai stabilitas yang disyaratkan.

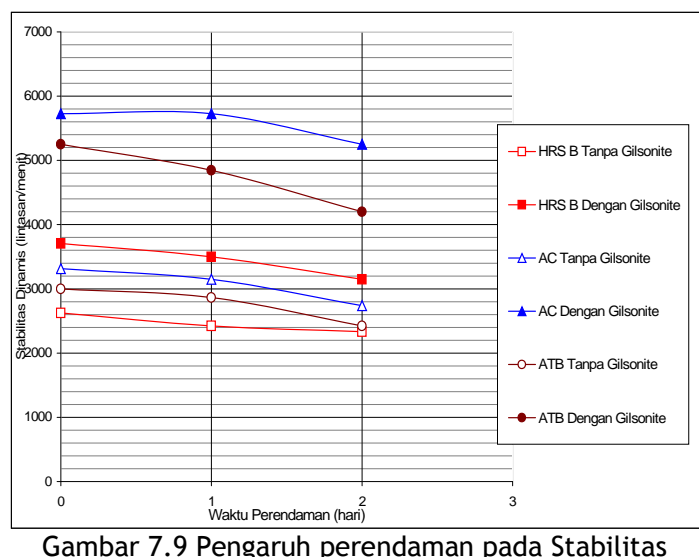

Penambahan Gilsonite ternyata memberikan hasil yang bagus terhadap nilai Stabilitas Marshall maupun Stabilitas Dinamis untuk ketiga jenis perkerasan yang direndam sampai 2 hari. Stabilitas Marshall yang didapatkan untuk campuran HRS B, AC dan ATB setelah direndam 2 hari berturut-turut adalah 1441, 1144, dan 1251 kg. Sedangkan Stabilitas Dinamis yang didapatkan dari Wheel Tracking Test untuk HRS B, AC, ATB yang telah direndam 2 hari adalah sebagai berikut: $\quad 3150, \quad 5250$ dan 4200 lintasan/menit. Dari hasil tersebut terlihat bahwa nilai Stabilitas Marshall maupun Dinamis untuk sample yang direndam 2 hari untuk ketiga jenis perkerasan yang di tes memberikan nilai yang lebih tinggi dari sample tanpa Gilsonite dan tanpa direndam. Hal ini menunjukkan bahwa penambahan Gilsonite Resin benar-benar dapat meningkatkan kualitas aspal prima baik peningkatan fisik aspal maupun peningkatan kekuatan campuran hot mix-nya.

\section{KESIMPULAN DAN SARAN 5.1 Kesimpulan}

Dari hasil percobaan di laboratorium, beberapa kesimpulan yang dapat diambil yaitu : 
- Hasil pengujian kualitas aspal prima 55 menunjukkan bahwa sifat-sifat fisik aspal: penetrasi, titik nyala dan titik lembek yang diuji tidak memenuhi persyaratan (spesifikasi aspal multigrade), kecuali berat jenis dan daktilitas. Dengan demikian kualitas aspal prima 55 perlu diperbaiki.

- Penambahan Gilsonite Resin dengan kadar $=6.8 \%$ dari berat aspal prima 55 ternyata dapat memperbaiki kualitas sifat-sifat fisik aspal prima 55 . Pencampuran Gilsonite tersebut memberikan kecenderungan nilai penetrasi aspal prima 55 makin menurun yaitu dari 73.4 pada kadar $0 \%$ menjadi 56,8 pada kadar $12 \%$. Penurunan nilai penetrasi ini memberikan indikasi akan menjadikan meningkatnya tingkat kekerasan campuran sehingga menambah kemampuan mendukung beban berat. Pengaruh sifat fisik yang lainnya adalah semakin tinggi kadar Gilsonite semakin tinggi pula nilai daktilitas, titik nyala maupun titik lembeknya. Nilai daktilitas yang tinggi berarti tingkat kohesinya semakin baik tetapi lebih peka terhadap perubahan temperatur. Namun apabila didasarkan pada hasil titik lembeknya yang semakin tinggi (dari $53.5^{\circ} \mathrm{C}$ pada $0 \%$ Gilsonite menjadi $71.5{ }^{\circ} \mathrm{C}$ pada penambahan gilsonite $12 \%$, ini berarti kepekaan terhadap perubahan temperatur bisa direduksi, sehingga dari segi tes fisik saja penambahan Gilsonite pada aspal prima 55 dapat memberikan peningkatkan terhadap kualitasnya.

- Berdasarkan hasil analisa Marshall untuk campuran HRS B, AC dan ATB, nilai Stabilitas yang diperoleh adalah berturut-turut 962, 1058 dan 1294 kg, sehingga masih memenuhi persyaratan (spesifikasi) yang ditetapkan. Disamping itu untuk syarat Marshall Quotient dan rongga dalam campuran untuk ketiga jenis hot mix yang dibuat dengan aspal prima 55 juga masuk dalam spesifikasi.

- Berdasarkan hasil uji Wheel Tracking, Stabilitas Dinamis untuk HRS B, AC dan ATB berturut-turut adalah 2625, 3316 dan 3000 lintasan/menit sehingga masih memenuhi spesifikasi yang ditetapkan.

- Akan tetapi pada hasil uji perendaman 2 hari, baik pada Uji Marshall maupun Wheel Tracking terjadi penurunan stabilitas yang cukup signifikan yaitu hasilnya berada dibawah spesifikasi yang ditetapkan. Sehingga dapat disimpulkan bahwa kualitas Hot Mix yang menggunakan aspal prima 55 kurang tahan terhadap pengaruh air.

- Penambahan Gilsonite pada aspal prima 55 ternyata dapat meningkatkan harga Stabilitas Marshall dan Stabilitas Dinamis yang cukup besar. Dan yang cukup menjanjikan adalah pengaruh perendaman perkerasan terhadap penurunan kekuatannya ternyata dapat direduksi, sehingga pemakaian Gilsonite ini sangat cocok untuk daerah yang rawan banjir.

- Dari hasil penelitian ini kadar Gilsonite yang perlu ditambahkan untuk masingmasing jenis perkerasan yang menggunakan aspal prima 55 adalah sebagai berikut: (i) untuk HRS B, Gilsonite yang perlu ditambahkan adalah $8 \%$ dari berat aspal optimum yang didapatkan; (ii) untuk AC, Gilsonite yang perlu ditambahkan adalah $6.8 \%$ dari berat aspal optimum yang didapatkan; dan (iii) untuk ATB, Gilsonite yang perlu ditambahkan adalah 9\% dari berat aspal optimum yang didapatkan.

\subsection{Saran}

Untuk menghindari kesulitan dalam pencampuran Gilsonite + Aspal prima 55 di AMP nantinya, karena pada saat pelaksanaan percobaan dilaboratorium sulit untuk mendapatkan campuran yang betul-betul homogen (sering terjadi penggumpalan), maka diperlukan suatu fabrikasi tersendiri untuk pencampuran Gilsonite dan Aspal Prima 55, sehingga pada saat pemakaian di Pugmill (AMP) sudah berupa aspal cair yang siap untuk disemprotkan pada agregat.

\section{DAFTAR PUSTAKA}

Bima Kimia Citra, P.T (1994), Upaya Peningkatan Mutu Stabilitas Perkerasan Jalan Dengan Penggunaan Bahan Pengaya Gilsonite Resin, (unpublished).

Bina Marga (2003), Teknologi Campuran Perkerasan Jalan Untuk Lalu-lintas Berat dan Padat, Jakarta 
Jurnal APLIKASI

ISSN.1907-753X

Brown, Stephen Professor (1990), The Shell Bitumen Handbook, Shell Bitumen U.K.

Direktorat Jenderal Bina Marga, Direktorat Bina Program Jalan, Second Nine Provinces Road, Rehabilitation Project, Buku 3, Spesifikasi Umum.

Puslitbang Jalan, Dept. PU (1993), Penelitian Bahan Gilsonite untuk Campuran Jenis $H R S$, (unpublished).

Basuki Rachmad (1997), Pengaruh Penambahan Gilsonite Resin Terhadap Kadar Aspal Optimum Pada Asphalt Concrete, Puslit-ITS.
Romagsa, Henry (1987), Gilsonite-An Asphalt Modifier for High Stability Pavement, proc.of Konferensi Tahunan Teknik Jalan III, Bandung.

Sukirman, Silvia (1992), Perkerasan Lentur Jalan Raya, Nova, Bandung.

Sutarno (2004), Pengaruh Air Laut terhadap Aspal Concrete yang Menggunakan Campuran Aspal prima 55, Tesis, MMTITS, Surabaya 